\title{
Benefit of Adding Ammonium Sulfate or Additional Glyphosate to Glyphosate in Corn and Soybean
}

\author{
Nader Soltani1, Robert E. Nurse'2, Christy Shropshire1, Peter H. Sikkema1 \\ ${ }^{1}$ University of Guelph Ridgetown Campus, Ridgetown, Canada \\ ${ }^{2}$ Agricuture and Agri-Food Canada, Harrow, Canada \\ Email: soltanin@uoguelph.ca
}

How to cite this paper: Soltani, N., Nurse, R.E., Shropshire, C. and Sikkema, P.H. (2016) Benefit of Adding Ammonium Sulfate or Additional Glyphosate to Glyphosate in Corn and Soybean. Agricultural Sciences, 7, 759770 .

http://dx.doi.org/10.4236/as.2016.710070

Received: September 14, 2016

Accepted: October 24, 2016

Published: October 27, 2016

Copyright $\odot 2016$ by authors and Scientific Research Publishing Inc. This work is licensed under the Creative Commons Attribution International License (CC BY 4.0).

http://creativecommons.org/licenses/by/4.0/ (c) (i) Open Access

\begin{abstract}
Nine field trials ( 4 in corn and 5 in soybean) were conducted over 2 years (2014 and 2015) to determine if there is greater benefit of adding ammonium sulfate (AMS) $\left(2.5 \mathrm{~L} \cdot \mathrm{ha}^{-1}\right)$ or an equal dollar value of glyphosate $\left(406 \mathrm{~g} \cdot \mathrm{ae} \cdot \mathrm{ha}^{-1}\right)$ to glyphosate applied at 450, 675 or 900 g.ae.ha ${ }^{-1}$ for weed control in corn and soybean. Glyphosate applied at 450 g.ae.ha ${ }^{-1}$ controlled velvetleaf $90 \%$ to $98 \%$, common ragweed $80 \%$ $97 \%$, common lambsquarters $91 \%$ - 99\%, Eastern black nightshade $83 \%-100 \%$ and barnyardgrass $73 \%-97 \%$ in corn and common ragweed $37 \%-89 \%$, common lambsquarters $39 \%$ - 98\%, barnyardgrass $90 \%-98 \%$ and green foxtail $91 \%-98 \%$ in soybean. The addition of AMS to glyphosate applied at 450, 675 or $900 \mathrm{~g} \cdot \mathrm{ae} \cdot \mathrm{ha}^{-1}$ provided little to no added benefit for the control of velvetleaf, common ragweed, common lambsquarters, Eastern black nightshade, barnyardgrass and green foxtail in corn and soybean. There was a greater benefit in weed control efficacy by simply adding and equal dollar value of glyphosate $\left(406 \mathrm{~g} \cdot \mathrm{ae} \cdot \mathrm{ha}^{-1}\right)$ than AMS $\left(2.5 \mathrm{~L} \cdot \mathrm{ha}^{-1}\right)$ to glyphosate. There was no difference in corn or soybean yield among the herbicide treatments evaluated. Based on these results, addition of AMS to glyphosate at rates evaluated had little benefit on weed control efficacy or yield of corn and soybean.
\end{abstract}

\section{Keywords}

Abutilon theophrasti, Ambrosia artemisiifolia, Corn (Zea mays),

Chenopodium album, Echinochloa crus-galli, Efficacy, Glyphosate, Setaria viridis,

Soybean (Glycine max), Yield

\section{Introduction}

The Ontario corn and soybean industry covers about 2,000,000 ha, and has annual 
farm-gate value of approximately $\$ 3.3$ billion [1]. Development of management strategies for the control of weeds in corn and soybean has been voted as the number one research priority by the Ontario Weed Committee (the voting members of the Ontario Weed Committee are representatives of the commodity groups such as corn, soybean, wheat and edible beans, industry personnel and public research scientists). Losses due to weeds include reduced yield, decreased quality, reduced field efficiency, and greater losses due to spoilage, increased dockage at the point of sale, and potential rejection of the crop.

Currently, more than $90 \%$ of the corn and $79 \%$ of soybean produced in Ontario are seeded to glyphosate-resistant hybrids/cultivars [2]. Glyphosate-resistant corn and soybean provide Ontario crop producers cost-effective weed management options that are efficacious and environmental friendly [3]. The net economic benefit to farmers is the main reason for wide adoption of this technology by crop producers in eastern Canada [4]. Despite glyphosate broad spectrum weed control, inconsistencies in control of some weed species have been reported at some locations which have been associated with water carrier solution [5] [6]. Nurse et al. [7] has shown benefit of adding AMS to glyphosate at low dose (225 g.ha $\left.{ }^{-1}\right)$ shortly after application (7 DAA) for control of velvetleaf (Abutilon theophrasti Medic.), however, at the same time there were no benefit for control of common lambsquarters (Chenopdium album L.), redroot pigweed (Amaranthus retroflexus L.), and annual grasses such as foxtails (Setaria spp.). It has been proposed that in the presence of AMS, the sulfate ion, $\mathrm{SO}_{4}^{2-}$ binds with $\mathrm{Ca}^{2+}$ to form $\mathrm{CaSO}_{4}$ and prevents formation of a Ca-salt of glyphosate, which is poorly absorbed by the leaves [6]. Instead $\mathrm{NH}_{4}^{+}$binds with the glyphosate molecule which results in greater absorption of glyphosate into the leaves and therefore improves weed control [6].

Limited information exists on the effect of ammonium sulfate added to glyphosate in corn and soybean under Ontario environmental conditions which can lead to unnecessary expenditures.

The objectives of this research were to determine the benefit of adding ammonium sulfate or an equal dollar value of glyphosate $\left(406 \mathrm{~g} \cdot \mathrm{ae} \cdot \mathrm{ha}^{-1}\right)$ to glyphosate applied at 450,675 or $900 \mathrm{~g} \cdot \mathrm{ae} \cdot \mathrm{ha}^{-1}$ for weed control in corn and soybean.

\section{Materials and Methods}

Four field trials ( 1 at Harrow in 2014 and 3 at Ridgetown in 2015) in corn and 5 field trials in soybean ( 1 at Harrow in 2014, 1 at Exeter in 2014 and 3 at Ridgetown in 2015) were conducted at the Agriculture and Agri-Food Canada Research Station, Harrow, Ontario, Huron Research Station, Exeter, Ontario and University of Guelph, Ridgetown Campus, Ridgetown, Ontario. The soil ranged from sandy loam to clay loam with $30 \%$ to $83 \%$ sand, $5 \%$ to $36 \%$ silt, and $13 \%$ to $33 \%$ clay, with $2.6 \%$ to $5.6 \%$ organic matter content and $\mathrm{pH} 6.0$ to 7.4. Seedbed preparation included fall mouldboard plowing followed by two passes with a field cultivator with rolling basket harrows in the spring.

Studies were established as a randomized complete block design with four replica- 
tions. Treatments for corn and soybean trials were the same and are listed in Tables 1-9. Weed-free control was maintained weed-free by hand hoeing as needed. Each plot was $3 \mathrm{~m}$ wide and 8 or $10 \mathrm{~m}$ long and consisted of four rows of glyphosate resistant corn/soybean spaced $0.75 \mathrm{~m}$ apart. Corn was planted at a rate of approximately 75,000 seeds.ha ${ }^{-1}$ in May of each year. Soybean was planted at a rate of approximately 370,000 seeds $\cdot \mathrm{ha}^{-1}$ in May to early June of each year.

Herbicide treatments were applied using a $\mathrm{CO}_{2}$-pressurized backpack sprayer calibrated to deliver $200 \mathrm{~L} \cdot \mathrm{ha}^{-1}$ aqueous solution at $240 \mathrm{kPa}$. The boom was $1.5 \mathrm{~m}$ wide with four ULD120-02 nozzles (Hypro, New Brighton, MN, USA) spaced $0.5 \mathrm{~m}$ apart. The herbicides were applied postemergence when weeds were approximately $10 \mathrm{~cm}$ in height which corresponded to the V2-4 stage for corn and V2-3 stage for soybean.

Weed control was visually estimated on a scale of 0 (no control) to $100 \%$ (complete control) at 1, 2, 3, 4 and 8 weeks after herbicide application (WAT). Weed density (soybean only) and dry weight (soybean only) by species were evaluated 4 WAT by counting and cutting plants at the soil surface form 1 square meter in each plot. Plants were dried at $60 \mathrm{C}$ to constant moisture and then weighed. Corn or soybean was harvested at maturity with a small plot combine, weight and moisture recorded and yields were adjusted to $15.5 \%$ and $13 \%$ seed moisture content for corn and soybean, respectively.

Data were analyzed using PROC GLIMMIX in Statistical Analysis Systems Software

Table 1. Percent visible control of velvetleaf 1, 2, 3, 4 and 8 WAT in corn with various rates of glyphosate alone or with AMS or additional glyphosate equivalent to the cost of the AMS at Ridgetown ON (2014-2015) ${ }^{\mathrm{a}}$.

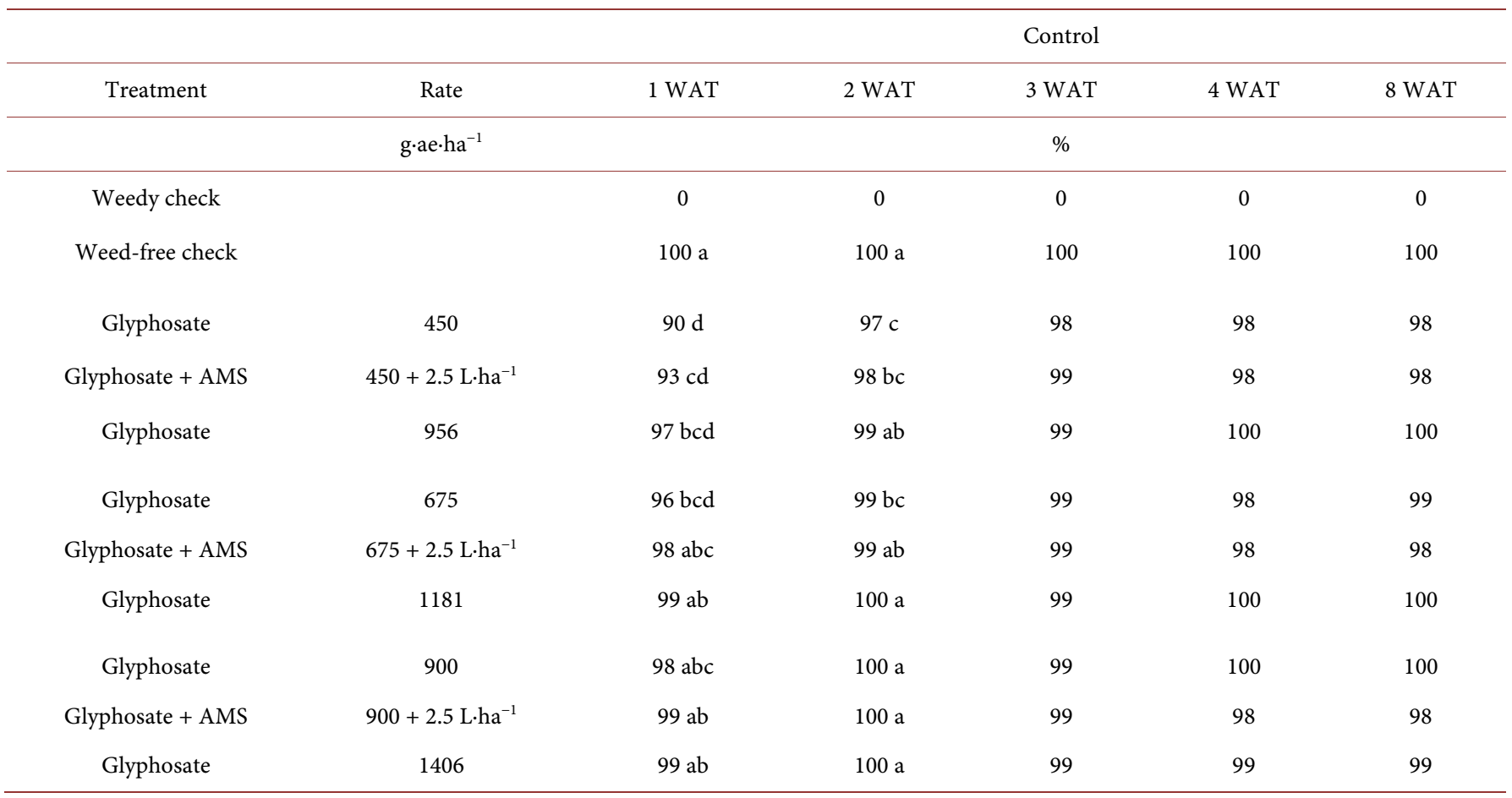

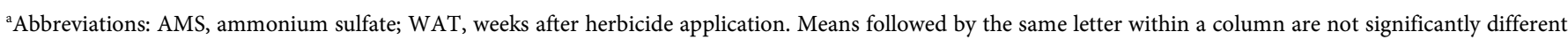
according to Fisher's Protected LSD at $\mathrm{P}<0.05$. 
Table 2. Percent visible control of common ragweed 1, 2, 3, 4 and 8 WAT in corn with various rates of glyphosate alone or with AMS or additional glyphosate equivalent to the cost of the AMS at Ridgetown ON (2014-2015) .

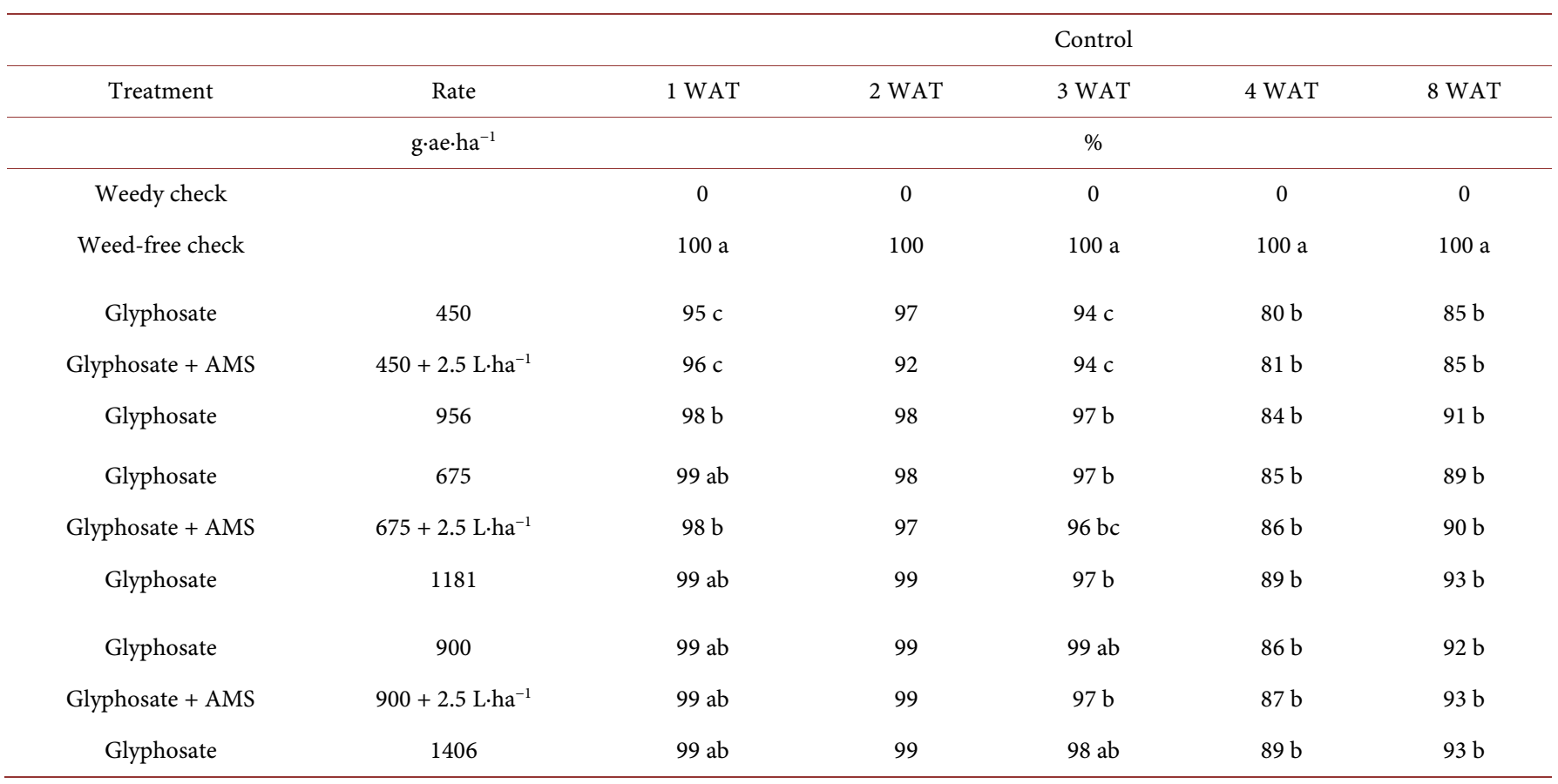

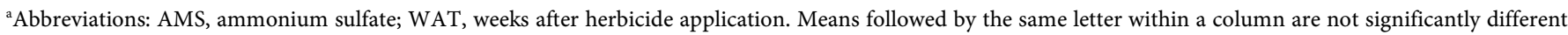
according to Fisher's Protected LSD at $\mathrm{P}<0.05$.

Table 3. Percent visible control of lambsquarters 1, 2, 3, 4 and 8 WAT in corn with various rates of glyphosate alone or with AMS or additional glyphosate equivalent to the cost of the AMS at Ridgetown and Harrow, ON (2014-2015) ${ }^{\text {a }}$.

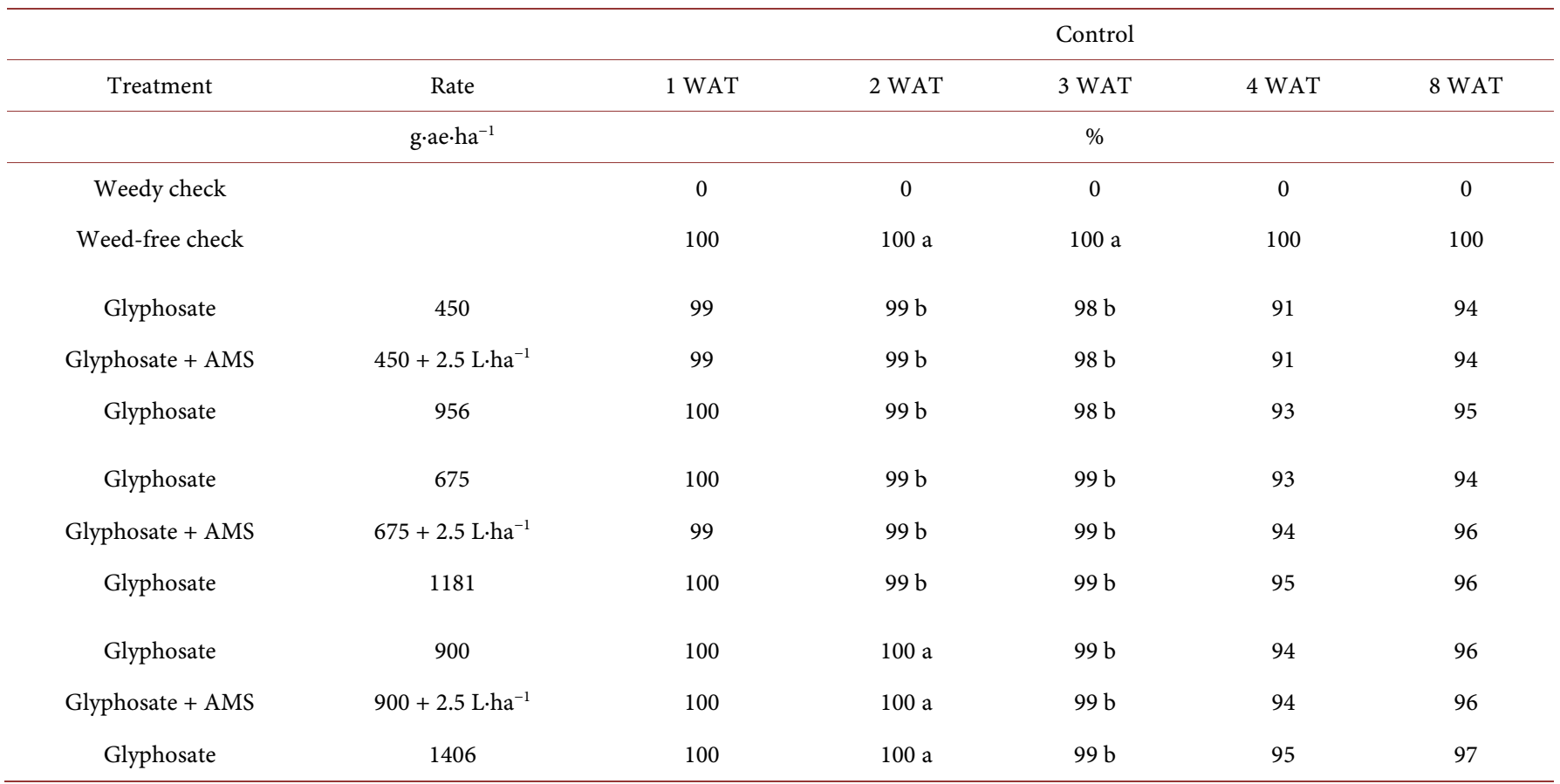

${ }^{a}$ Abbreviations: AMS, ammonium sulfate; WAT, weeks after herbicide application. Means followed by the same letter within a column are not significantly different according to Fisher's Protected LSD at $\mathrm{P}<0.05$. 
Table 4. Percent visible control of Eastern black nightshade 1, 2, 3, 4 and 8 WAT in corn with various rates of glyphosate alone or with AMS or additional glyphosate equivalent to the cost of the AMS at Ridgetown and Harrow, ON (2014-2015) .

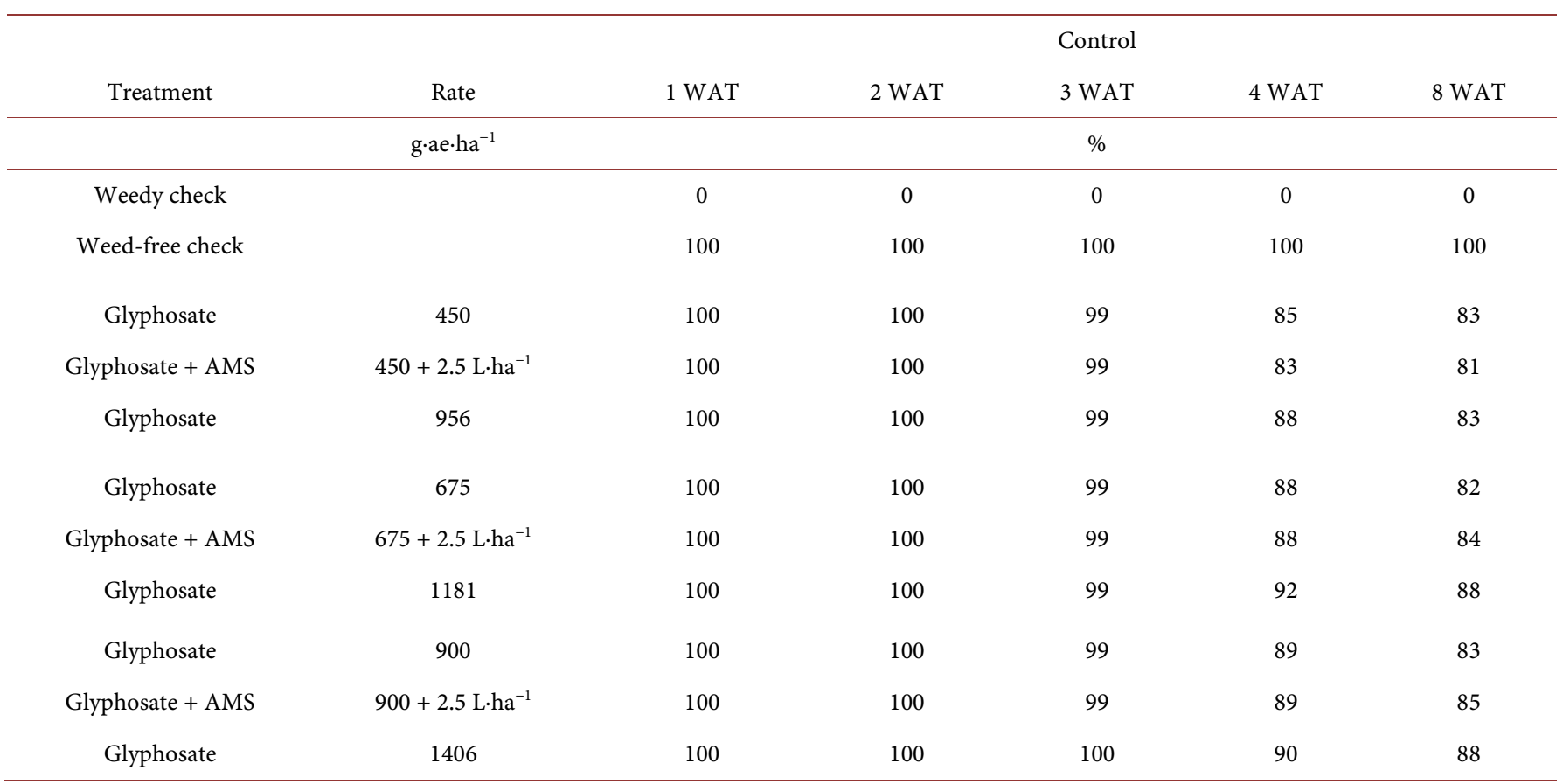

${ }^{a}$ Abbreviations: AMS, ammonium sulfate; WAT, weeks after herbicide application. Means followed by the same letter within a column are not significantly different according to Fisher's Protected LSD at $\mathrm{P}<0.05$.

Table 5. Corn yield and percent visible control of barnyardgrass 1,2,3,4 and 8 WAT in corn with various rates of glyphosate alone or with AMS or additional glyphosate equivalent to the cost of the AMS at Ridgetown and Harrow, ON (2014-2015).

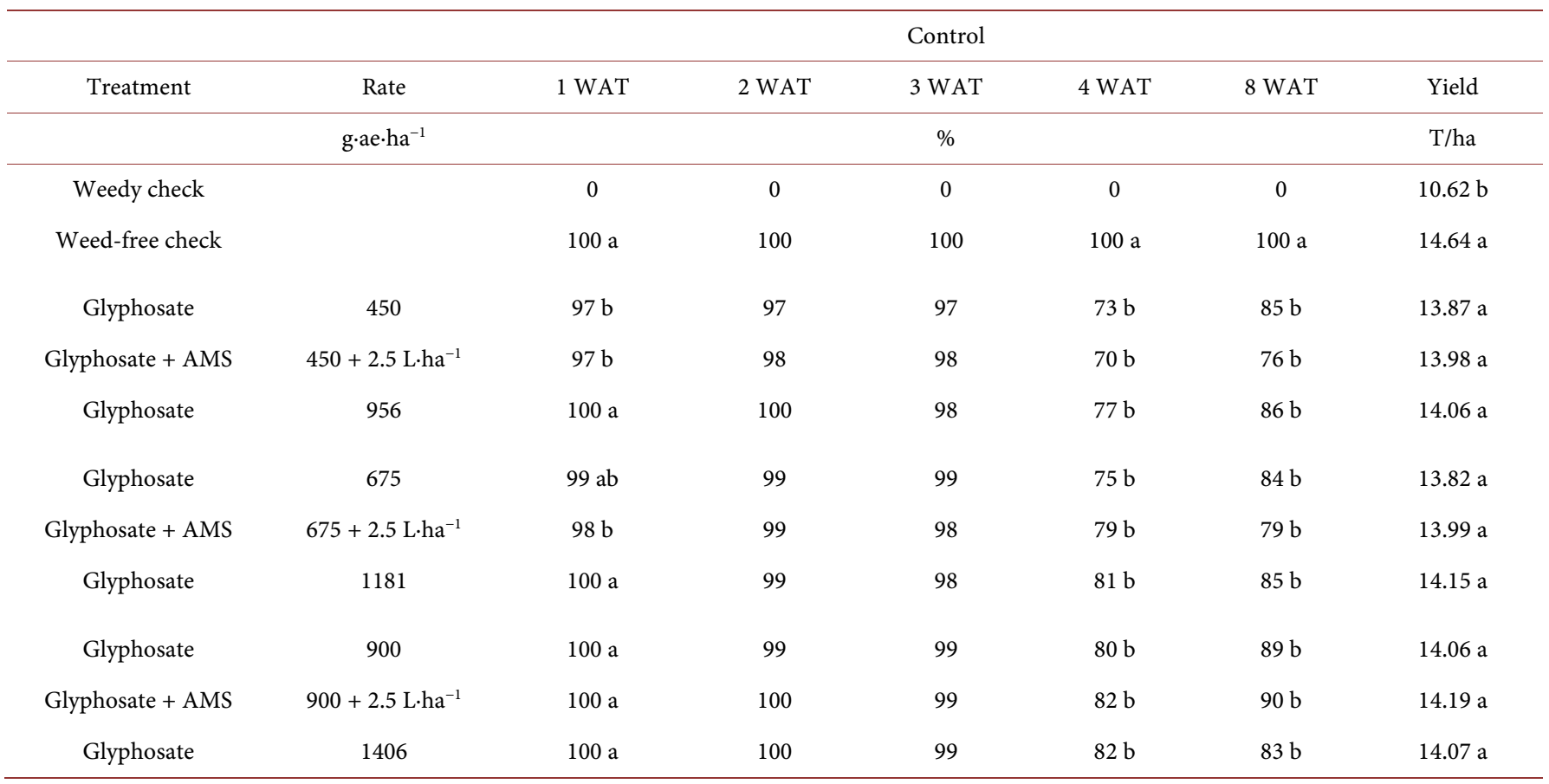

${ }^{a}$ Abbreviations: AMS, ammonium sulfate; WAT, weeks after herbicide application. Means followed by the same letter within a column are not significantly different according to Fisher's Protected LSD at $\mathrm{P}<0.05$. 
Table 6. Percent visible control of common ragweed 1, 2, 3, 4 and 8 WAT in soybean with various rates of glyphosate alone or with AMS or additional glyphosate equivalent to the cost of the AMS at Ridgetown, Exeter and Harrow ON (2014-2015) ${ }^{\text {a }}$.

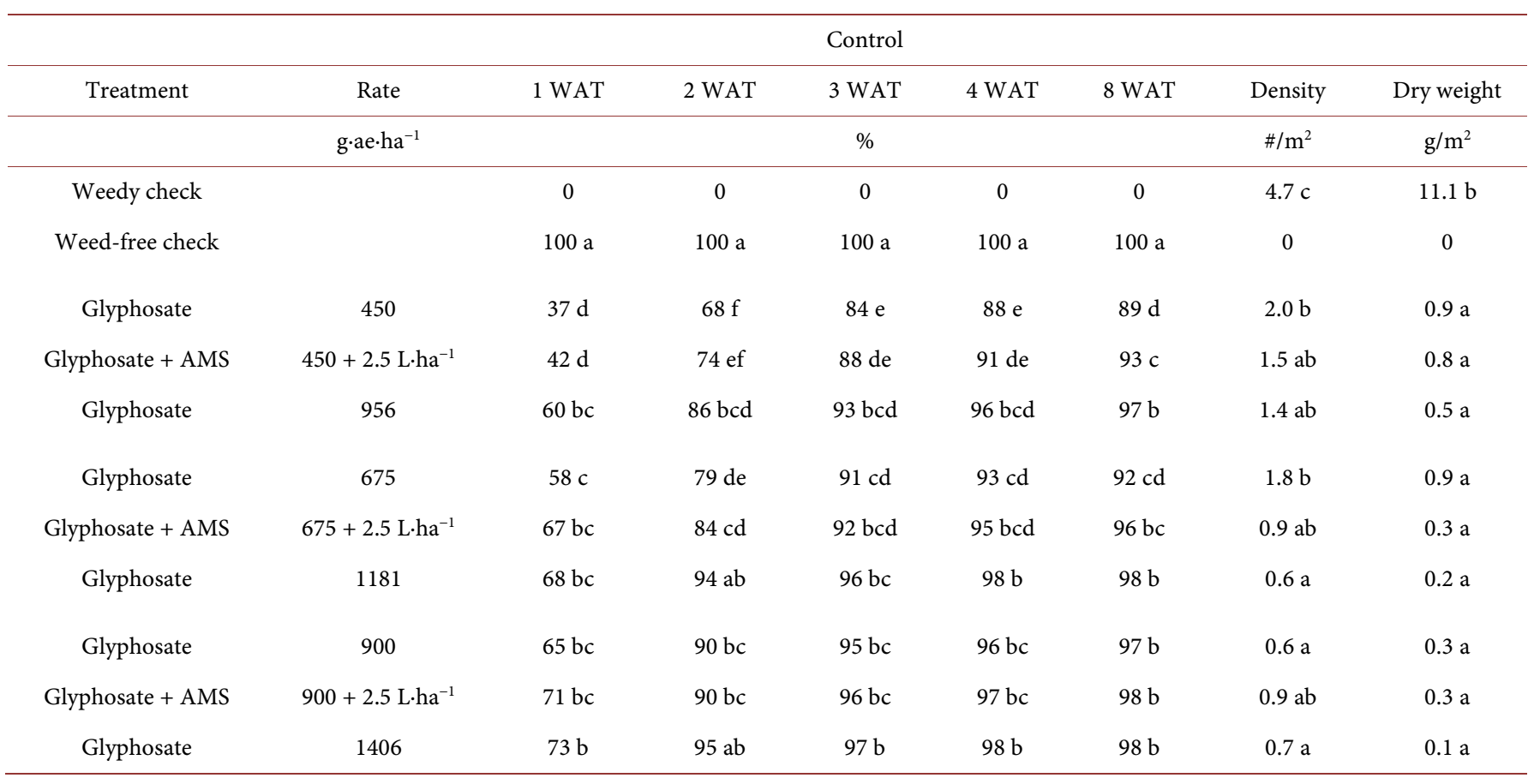

${ }^{a}$ Abbreviations: AMS, ammonium sulfate; WAT, weeks after herbicide application. Means followed by the same letter within a column are not significantly different according to Fisher's Protected LSD at $\mathrm{P}<0.05$.

Table 7. Percent visible control of lambsquarters 1, 2, 3, 4 and 8 WAT in soybean with various rates of glyphosate alone or with AMS or additional glyphosate equivalent to the cost of the AMS at Ridgetown, Exeter and Harrow ON (2014-2015) .

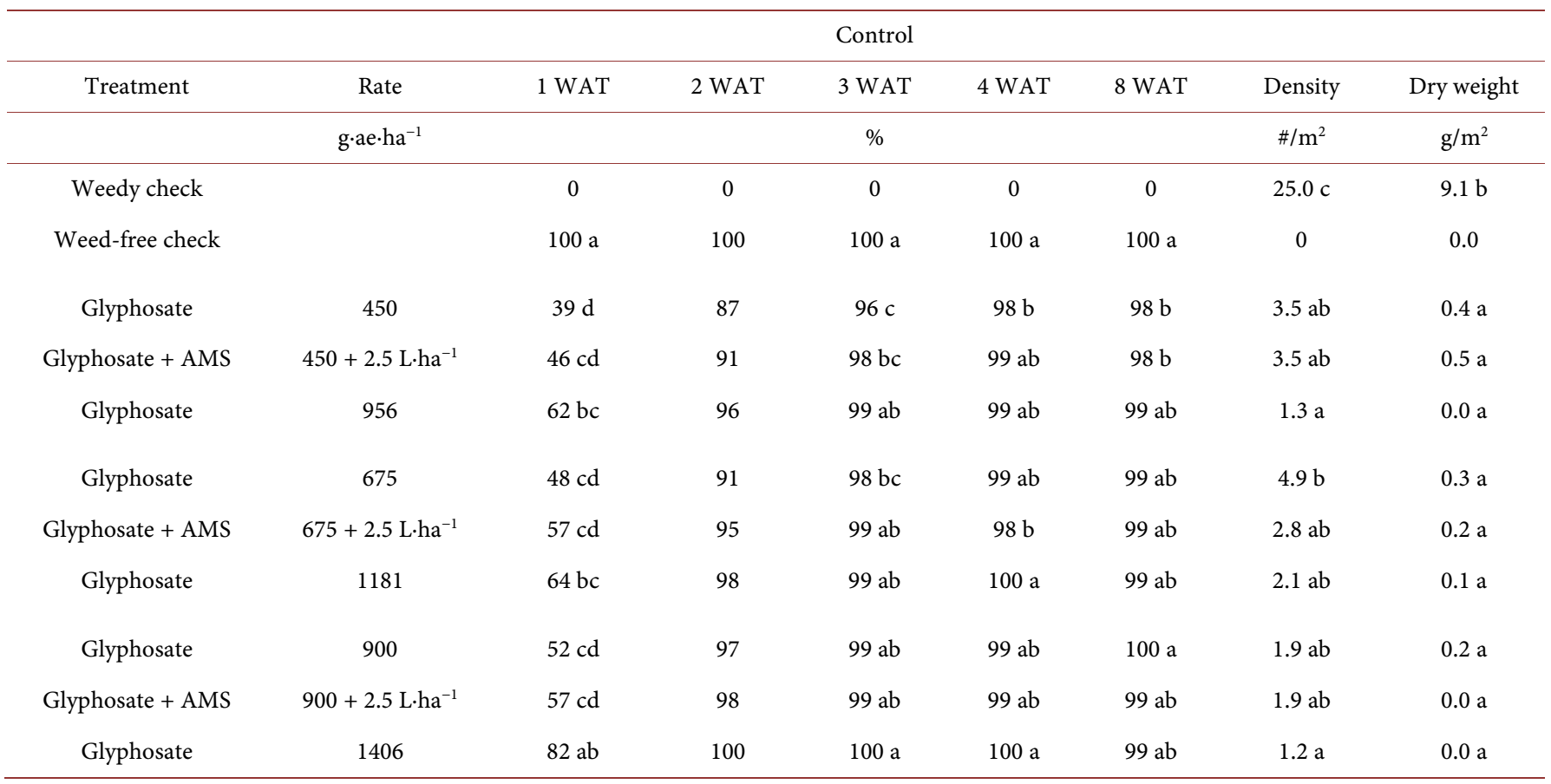

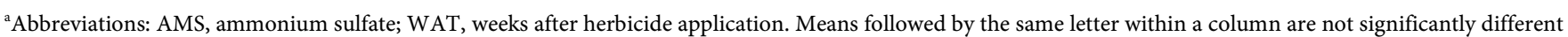
according to Fisher's Protected LSD at $\mathrm{P}<0.05$. 
Table 8. Percent visible control of barnyardgrass 1, 2, 3, 4 and 8 WAT in soybean with various rates of glyphosate alone or with AMS or additional glyphosate equivalent to the cost of the AMS at Ridgetown, Exeter and Harrow ON (2014-2015) .

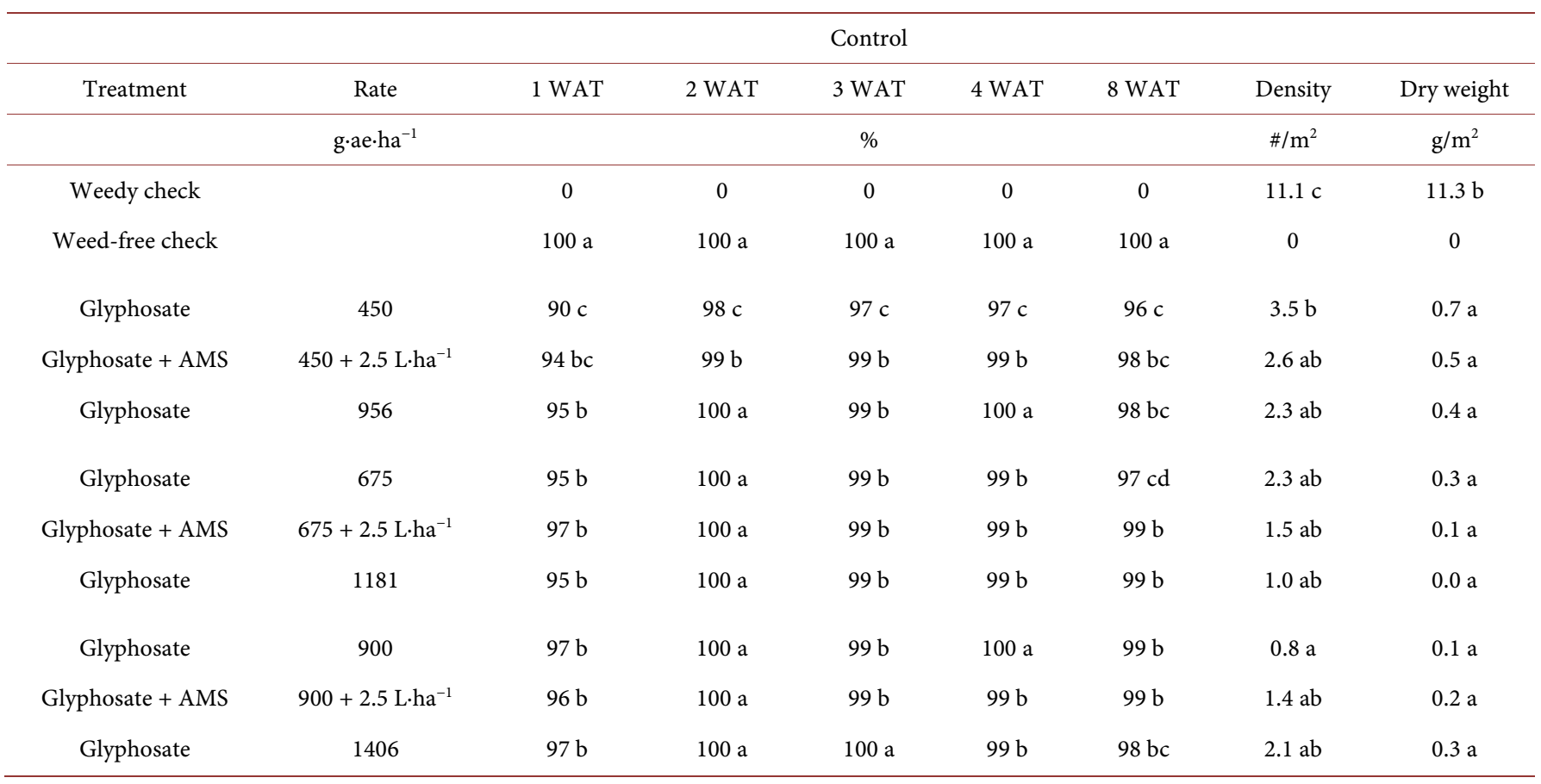

${ }^{a}$ Abbreviations: AMS, ammonium sulfate; WAT, weeks after herbicide application. Means followed by the same letter within a column are not significantly different according to Fisher's Protected LSD at $\mathrm{P}<0.05$.

Table 9. Corn yield and percent visible control of green foxtail 1,2,3,4 and 8 WAT in soybean with various rates of glyphosate alone or with AMS or additional glyphosate equivalent to the cost of the AMS at Ridgetown and Exeter ON (2014-2015) ${ }^{\text {a }}$.

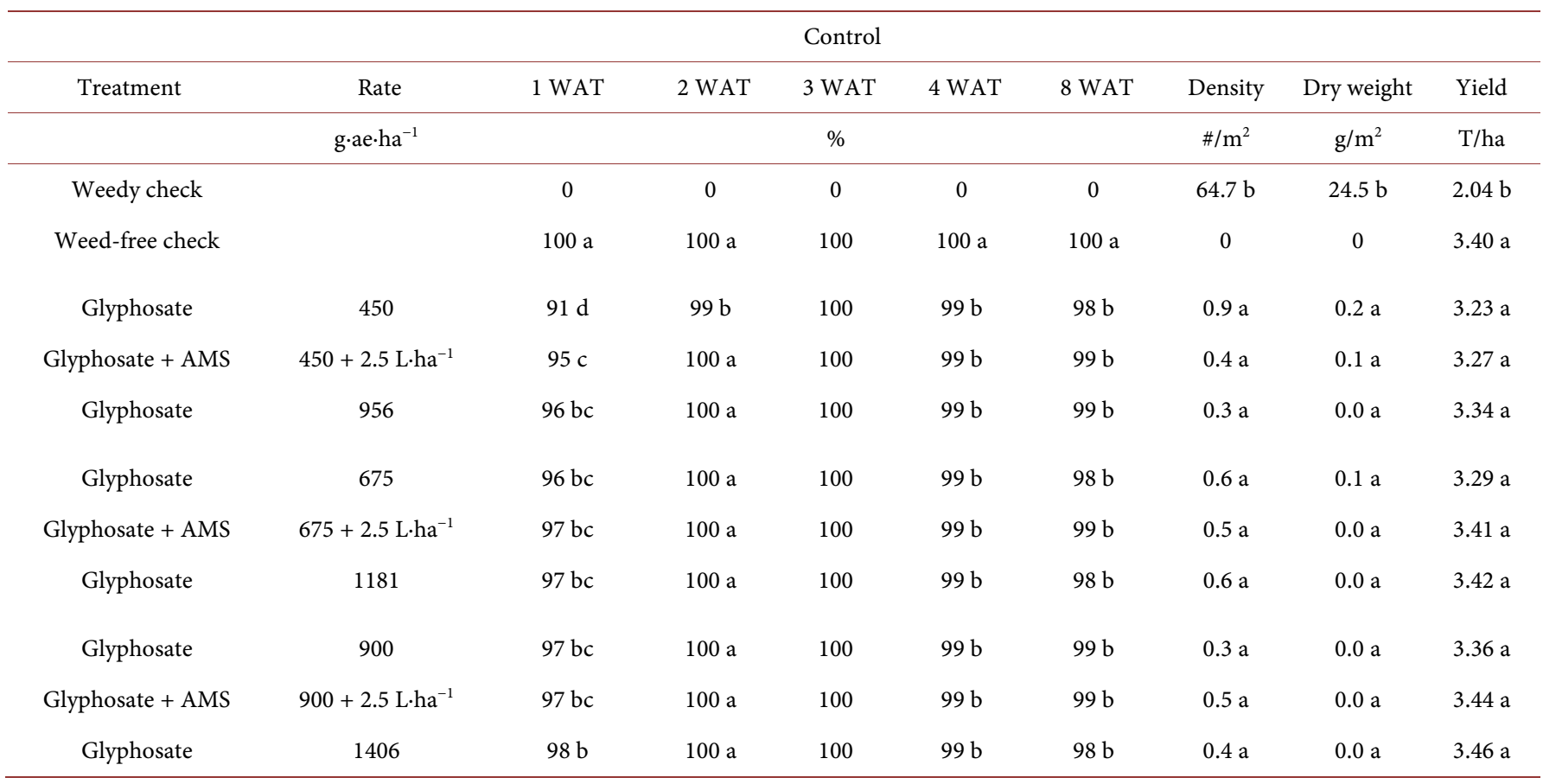

${ }^{a}$ Abbreviations: AMS, ammonium sulfate; WAT, weeks after herbicide application. Means followed by the same letter within a column are not significantly different according to Fisher's Protected LSD at $\mathrm{P}<0.05$. 
(SAS) [8]. Herbicide treatment was considered a fixed effect, while random effects included environment (year-location combinations), environment by herbicide treatment interaction, and replicate nested within environment. Significance of the fixed effect was tested using the F-test and random effects were tested using a likelihood ratio. Residual plots were used to check that variances were randomly distributed, independent and homogeneous. The Laplace method was used for estimation method; weed control and yield were analyzed using a normal distribution and identity link and weed density and dry weight were analyzed using a lognormal distribution and identity link. Data were square root or arcsine square root transformed prior to analysis when necessary. Treatment comparisons were made using Fisher's Protected LSD at $\mathrm{P}<0.05$. Data compared on the transformed scale were converted back to the original scale for presentation of results.

\section{Results and Discussion}

Data were pooled and averaged over years and locations when there was no statistically significant interaction between year, location and treatments (Tables 1-9). Weeds were included when present in 3 or more trials.

\subsection{Corn Trials}

There was no observable corn injury for any of the treatments tested (data not shown). For corn trials the predominant weed species included velvetleaf, common ragweed, common lambsquarters, Eastern black nightshade and barnyardgrass.

Glyphosate applied at 450, 675 and $900 \mathrm{~g} \cdot a \mathrm{ae} \cdot \mathrm{ha}^{-1}$ controlled velvetleaf $90 \%$ - 98\%, $96 \%-99 \%$ and $98 \%-100 \%$, respectively (Table 1 ). Generally, the addition of AMS ( 2.5 $\mathrm{L} \cdot \mathrm{ha}^{-1}$ ) or glyphosate (406 g.ae.ha ${ }^{-1}$, same dollar value as AMS) to glyphosate at 450, 675 and $900 \mathrm{~g} \cdot \mathrm{ae} \cdot \mathrm{ha}^{-1}$ did not result in increased velvetleaf control at 1, 2, 3, 4 and 8 WAT. There were two exceptions, at $2 \mathrm{WAT}$, velvetleaf control was improved with the addition of glyphosate ( $406 \mathrm{~g} \cdot \mathrm{ae} \cdot \mathrm{ha}^{-1}$ ) to glyphosate at 450 and $675 \mathrm{~g} \cdot \mathrm{ae} \cdot \mathrm{ha}^{-1}$ (Table 1).

Glyphosate applied at 450, 675 and $900 \mathrm{~g} \cdot \mathrm{ae} \cdot \mathrm{ha}^{-1}$ controlled common ragweed $80 \%$ 97\%, 85\% - 99\% and 86\% - 99\%, respectively (Table 2). The addition of AMS (2.5 $\mathrm{L} \cdot \mathrm{ha}^{-1}$ ) to glyphosate (at 450, 675 and $900 \mathrm{~g} \cdot \mathrm{ae} \cdot \mathrm{ha}^{-1}$ ) did not provide any added benefit in controlling common ragweed at 1, 2, 3, 4 and 8 WAT (Table 2). The addition of glyphosate (406 g.ae $\cdot \mathrm{ha}^{-1}$, same dollar value as AMS) to glyphosate at $450 \mathrm{~g} \cdot \mathrm{ae} \cdot \mathrm{ha}^{-1} \mathrm{im}$ proved the control of common ragweed at 1 and 3 WAT (Table 2).

Glyphosate applied at 450, 675 and $900 \mathrm{~g} \cdot \mathrm{ae} \cdot \mathrm{ha}^{-1}$ controlled common lambsquarters $91 \%-99 \%, 93 \%-100 \%$ and $94 \%-100 \%$, respectively (Table 3 ). The addition of AMS $\left(2.5 \mathrm{~L} \cdot \mathrm{ha}^{-1}\right.$ ) or glyphosate (406 g.ae $\cdot \mathrm{ha}^{-1}$, same dollar value as AMS) to glyphosate (at 450, 675 and $900 \mathrm{~g} \cdot \mathrm{ae} \cdot \mathrm{ha}^{-1}$ ) did not improve control of common lambsquarters at 1, 2, 3, 4 and 8 WAT (Table 3 ).

Glyphosate applied at 450, 675 and $900 \mathrm{~g} \cdot \mathrm{ae} \cdot \mathrm{ha}^{-1}$ controlled Eastern black nightshade $82 \%-100 \%$ (Table 4). There was no improvement in the control of Eastern black nightshade control with the addition of AMS $\left(2.5 \mathrm{~L} \cdot \mathrm{ha}^{-1}\right)$ or glyphosate (406 g.ae.ha ${ }^{-1}$, 
same dollar value as AMS) to glyphosate at 450, 675 and $900 \mathrm{~g} \cdot \mathrm{ae} \cdot \mathrm{ha}^{-1}$ (Table 4).

Glyphosate applied at 450, 675, $900 \mathrm{~g} \cdot \mathrm{ae}^{\mathrm{h}} \mathrm{ha}^{-1}$ controlled barnyardgrass 73\% - 97\%, $75 \%-99 \%$ and $80 \%-100 \%$, respectively (Table 5). Generally, the addition of AMS ( 2.5 $\mathrm{L} \cdot \mathrm{ha}^{-1}$ ) or glyphosate (406 g.ae.ha ${ }^{-1}$, same dollar value as AMS) to glyphosate at 450,675 and $900 \mathrm{~g} \cdot \mathrm{ae} \cdot \mathrm{ha}^{-1}$ did not result in increased barnyardgrass control at 1, 2, 3, 4 and 8 WAT. There were two exceptions, at $1 \mathrm{WAT}$, barnyardgrass control was improved with the addition of glyphosate ( $406 \mathrm{~g} \cdot \mathrm{ae} \cdot \mathrm{ha}^{-1}$ ) to glyphosate at $450 \mathrm{~g} \cdot \mathrm{ae} \cdot \mathrm{ha}^{-1}$ and barnyardgrass control was greater with glyphosate at $1181 \mathrm{~g} \cdot \mathrm{ae} \cdot \mathrm{ha}^{-1}$ compared to glyphosate $\left(675 \mathrm{~g} \cdot \mathrm{ae} \cdot \mathrm{ha}^{-1}\right)$ plus AMS $\left(2.5 \mathrm{~L} \cdot \mathrm{ha}^{-1}\right)$ (Table 5).

Reduced weed interference with glyphosate applied at 450, 675, $900 \mathrm{~g} \cdot \mathrm{ae} \cdot \mathrm{ha}^{-1}$ resulted in corn yields that were equivalent to the weed-free check (Table 5). The addition of AMS (2.5 L.ha ${ }^{-1}$ ) or glyphosate (406 g.ae $\cdot \mathrm{ha}^{-1}$, same dollar value as AMS) to glyphosate (450, 675 and 900 g.ae $\cdot \mathrm{ha}^{-1}$ ) did not result in increased corn yield (Table 5).

Results are similar to other studies that have shown no improvement in control of velvetleaf, redroot pigweed, common lambsquarters and annual grasses when AMS was added to glyphosate [9]. However, Pratt et al. [5] reported greater control of velvetleaf when AMS was added to glyphosate compared to glyphosate alone. Nurse et al. (2008) and Young et al. [10] have reported that velvetleaf control is enhanced with the addition of AMS to glyphosate. Nurse et al. [7] and Young et al. [10] found that the control of other weed species such as common lambsquarters does not always improve with the addition of AMS to glyphosate. It should be noted that all of these studies only reported a benefit of the addition of AMS to glyphosate at glyphosate doses $<450 \mathrm{~g} \cdot \mathrm{ae} \cdot \mathrm{ha}^{-1}$, which is half the labeled dose in Ontario.

\subsection{Soybean Trials}

There was no observable soybean injury for any of the treatments tested (data not shown). For soybean trials the predominant weed species included common ragweed, common lambsquarters, barnyardgrass and green foxtail.

Glyphosate applied at 450, 675 and $900 \mathrm{~g} \cdot \mathrm{ae} \cdot \mathrm{ha}^{-1}$ controlled common ragweed 37\% $89 \%, 58 \%-93 \%$ and $65 \%-97 \%$, respectively (Table 6). Generally, the addition of AMS $\left(2.5 \mathrm{~L} \cdot \mathrm{ha}^{-1}\right)$ to glyphosate $\left(450,675\right.$ and $\left.900 \mathrm{~g} \cdot \mathrm{ae} \cdot \mathrm{ha}^{-1}\right)$ did not result in an increase in common ragweed control at 1,2, 3, 4 and 8 WAT in soybean, with one exception, at 8 WAT, common ragweed control was improved with the addition of AMS $\left(2.5 \mathrm{~L} \cdot \mathrm{ha}^{-1}\right)$ to glyphosate at $450 \mathrm{~g} \cdot \mathrm{ae} \cdot \mathrm{ha}^{-1}$ (Table 6). Conversely, at 1, 2, 3, 4 and 8 WAT the addition of glyphosate ( $406 \mathrm{~g} \cdot \mathrm{ae} \cdot \mathrm{ha}^{-1}$ ) to glyphosate at $450 \mathrm{~g} \cdot \mathrm{ae} \cdot \mathrm{ha}^{-1}$ consistently resulted in improved control of common ragweed. Similarly, at 2, 4 and 8 WAT the addition of glyphosate (406 g.ae $\cdot \mathrm{ha}^{-1}$ ) to glyphosate at $675 \mathrm{~g} \cdot \mathrm{ae} \cdot \mathrm{ha}^{-1}$ resulted in improved control of common ragweed. There was no decrease in common ragweed density and dry weight with the addition of AMS $\left(2.5 \mathrm{~L} \cdot \mathrm{ha}^{-1}\right)$ or additional glyphosate $\left(406 \mathrm{~g} \cdot \mathrm{ae} \cdot \mathrm{ha}{ }^{-1}\right)$ to glyphosate at 450, 675 and $900 \mathrm{~g} \cdot \mathrm{ae} \cdot \mathrm{ha}^{-1}$ (Table 6).

Glyphosate applied at 450, 675 and $900 \mathrm{~g} \cdot \mathrm{ae} \cdot \mathrm{ha}^{-1}$ controlled common lambsquarters $39 \%-98 \%, 48 \%-99 \%$ and 52\% - 100\%, respectively (Table 7). The addition of AMS 
$\left(2.5 \mathrm{~L} \cdot \mathrm{ha}^{-1}\right.$ ) to glyphosate (at 450,675 and $900 \mathrm{~g} \cdot \mathrm{ae} \cdot \mathrm{ha}^{-1}$ ) did not improve control of common lambsquarters at 1, 2, 3, 4 and 8 WAT. At 1 and 3 WAT the addition of glyphosate (406 g.ae $\cdot \mathrm{ha}^{-1}$ ) to glyphosate at $450 \mathrm{~g} \cdot \mathrm{ae} \cdot \mathrm{ha}^{-1}$ resulted in improved control of lambsquarters. Lambsquarters control was greater with glyphosate at $1181 \mathrm{~g} \cdot a \mathrm{ae} \cdot \mathrm{ha}^{-1}$ compared to glyphosate (675 g.ae $\cdot \mathrm{ha}^{-1}$ ) plus AMS at $2.5 \mathrm{~L} \cdot \mathrm{ha}^{-1}$ (Table 7). The addition of AMS or glyphosate (406 g.ae.ha ${ }^{-1}$, same dollar value as AMS) to glyphosate (450, 675 and $900 \mathrm{~g} \cdot \mathrm{ae} \cdot \mathrm{ha}^{-1}$ ) did not or decrease common lambsquarters density and dry weight (Table 7).

Glyphosate applied at 450, 675 and $900 \mathrm{~g} \cdot \mathrm{ae}^{\mathrm{ha}} \mathrm{h}^{-1}$ controlled barnyardgrass $90 \%$ $98 \%, 95 \%-100 \%$ and $97 \%-100 \%$, respectively (Table 8). At 2, 3 and 4 WAT, the addition of AMS (2.5 L.ha $\left.{ }^{-1}\right)$ to glyphosate $450 \mathrm{~g} \cdot \mathrm{ae}^{\mathrm{h}} \mathrm{ha}^{-1}$ improved the control of barnyardgrass; at $8 \mathrm{WAT}$, the addition of AMS $\left(2.5 \mathrm{~L} \cdot \mathrm{ha}^{-1}\right)$ to glyphosate $675 \mathrm{~g} \cdot \mathrm{ae} \cdot \mathrm{ha}^{-1} \mathrm{im}$ proved the control of barnyardgrass; and at $4 \mathrm{WAT}$, the addition of AMS $\left(2.5 \mathrm{~L} \cdot \mathrm{ha}^{-1}\right)$ to glyphosate $900 \mathrm{~g} \cdot \mathrm{ae} \cdot \mathrm{ha}^{-1}$ decreased control of barnyardgrass but there was no decrease in barnyardgrass density or dry weight (Table 8). At 1,2, 3 and 4 WAT, the addition of additional glyphosate (406 g.ae $\cdot \mathrm{ha}^{-1}$, same dollar value as AMS) to glyphosate 450 g.ae.ha ${ }^{-1}$ improved the control of barnyardgrass; at $8 \mathrm{WAT}$, the addition of additional glyphosate (406 g.ae $\cdot \mathrm{ha}^{-1}$, same dollar value as AMS) to glyphosate $675 \mathrm{~g} \cdot \mathrm{ae} \cdot \mathrm{ha}^{-1} \mathrm{im}$ proved the control of barnyardgrass; and at 3 WAT, the addition of additional glyphosate (406 g.ae $\cdot \mathrm{ha}^{-1}$, same dollar value as AMS) to glyphosate $900 \mathrm{~g} \cdot \mathrm{ae} \cdot \mathrm{ha}^{-1}$ improved the control of barnyardgrass but there was no decrease in barnyardgrass density or dry weight (Table 8). Interestingly the addition of AMS (2.5 L $\left.\cdot \mathrm{ha}^{-1}\right)$ and additional glyphosate to glyphosate $900 \mathrm{~g} \cdot \mathrm{ae} \cdot \mathrm{ha}^{-1}$ reduced barnyardgrass control at 4 WAT. No explanation is provided for this observation and the difference in all likelihood can be attributed to experimental variation.

Glyphosate applied at 450, 675 and $900 \mathrm{~g} \cdot \mathrm{ae} \cdot \mathrm{ha}^{-1}$ controlled green foxtail 91\% - 100\%, $96 \%-100 \%$ and $97 \%-100 \%$, respectively (Table 9 ). At 1 and 2 WAT, the addition AMS $\left(2.5 \mathrm{~L} \cdot \mathrm{ha}^{-1}\right)$ or additional glyphosate $\left(406 \mathrm{~g} \cdot \mathrm{ae} \cdot \mathrm{ha}^{-1}\right)$ to glyphosate (450 g.ae $\cdot \mathrm{ha}^{-1}$ ) improved the control of green foxtail. There was no improvement in green foxtail control when AMS (2.5 L·ha ${ }^{-1}$ ) or additional glyphosate ( $\left.406 \mathrm{~g} \cdot \mathrm{ae} \cdot \mathrm{ha}^{-1}\right)$ was added to glyphosate at 675 and $900 \mathrm{~g} \cdot a \mathrm{ae} \cdot \mathrm{ha}^{-1}$ and no decrease in green foxtail density and dry weight (Table 9).

Reduced weed interference with glyphosate applied at 450, 675 and 900 g.ae.ha ${ }^{-1}$ resulted in soybean yields that were equivalent to the weed-free check (Table 9). The addition of AMS (2.5 L.ha ${ }^{-1}$ ) or additional glyphosate (406 g.ae.ha ${ }^{-1}$, same dollar value as AMS) to glyphosate at 450, 675 and $900 \mathrm{~g} \cdot \mathrm{ae}^{\mathrm{h}} \mathrm{ha}^{-1} \mathrm{did}$ not result in increased soybean yield (Table 9). In other studies, Nurse et al. [7] and Soltani et al. [9] also reported no difference in yield when AMS was added to a full labeled rate of glyphosate (900 $\left.\mathrm{g} \cdot \mathrm{ae} \cdot \mathrm{ha}^{-1}\right)$.

\section{Conclusion}

The addition of AMS or an equal dollar value of glyphosate to glyphosate applied at 
450, 675 or $900 \mathrm{~g} \cdot a \mathrm{a} \cdot \mathrm{ha}^{-1}$ provided no consistent benefit for the control of velvetleaf, common ragweed, common lambsquarters, Eastern black nightshade and barnyardgrass in corn and common ragweed, common lambsquarters, barnyardgrass and green foxtail in soybean. There was no difference in corn or soybean yield among the herbicide treatments evaluated. The similar levels of weed control provided by the herbicide treatments evaluated provide a plausible reason for there being no effect of adding AMS or additional glyphosate to glyphosate on corn or soybean yield. Based on these results, the addition of AMS to glyphosate at the full label rate had little benefit on weed control efficacy and corn and soybean yield under Ontario environmental conditions.

\section{Acknowledgements}

The authors acknowledge Todd Cowan, Lynette Brown and Elaine Lepp for their expertise and technical assistance in these studies. This research was funded in part by the Grain Farmers of Ontario (GFO) and the GF2 program of the Agricultural Adaptation Council.

\section{References}

[1] Kulasekera, B. (2015) Estimated Area, Yield, Production and Farm Value of Specified Field Crops, Ontario, 2011-2015 (Imperial and Metric Units), 2011-2015, (Metric Units). http://www.omafra.gov.on.ca/english/stats/crops/estimate_new.htm

[2] Beckie, H.J., Sikkema, P.H., Soltani, N., Blackshaw, R.E. and Johnson, E.N. (2014) Environmental Impact of Glyphosate-Resistant Weeds in Canada. Weed Science, 62, 385-392. http://dx.doi.org/10.1614/WS-D-13-00093.1

[3] Sikkema, P.H. and Soltani, N. (2007) Herbicide-Resistant Crops in Eastern Canada. In: Gulden, R.H. and Swanton, C.J., Eds., The First Decade of Herbicide-Resistant Crops in Canada, Vol. 4, Canadian Weed Science Society—Societe Canadienne de malherbologie, Sainte Anne de Bellevue, 3-13.

[4] Beckie, H.J., Harker, K.N., Hall, L.M., Warwick, S.I., Legere, A., Sikkema, P.H., Clayton, G.W., Thomas, A.G., Leeson, J.Y., Sequin-Swartz, G. and Simard, M.J. (2006) A Decade of Herbicide-Resistant Crops in Canada. Canadian Journal of Plant Science, 86, 1243-1264. http://dx.doi.org/10.4141/P05-193

[5] Pratt, D., Kells, J.J. and Penner, D. (2003) Substitutes for Ammonium Sulfate as Additives with Glyphosate and Glufosinate. Weed Technology, 17, 576-581. http://dx.doi.org/10.1614/0890-037X(2003)017[0576:SFASAA]2.0.CO;2

[6] Thelen, K.D., Jackson, E.P. and Penner, D. (1995) The Basis for the Hard-Water Antagonism of Glyphosate Activity. Weed Science, 43, 541-548.

[7] Nurse, R.E., Hamill, A.S., Kells, J.J. and Sikkema, P.H. (2008) Annual Weed Control May Be Improved When AMS Is Added to Below-Label Glyphosate Doses in Glyphosate-Tolerant Maize (Zea mays L.). Crop Protection, 27, 452-458.

http://dx.doi.org/10.1016/j.cropro.2007.07.015

[8] Statistical Analysis Systems (2008) The SAS System. Version 9.2, Statistical Analysis Systems Institute, Cary.

[9] Soltani, N., Nurse, R.E., Robinson, R.E. and Sikkema, P.H. (2011) Effect of Ammonium Sulfate and Water Hardness on Glyphosate and Glufosinate Activity in Corn. Canadian Journal of Plant Science, 91, 1053-1059. http://dx.doi.org/10.4141/cjps2011-047 
[10] Young, B.G., Knepp, A.W., Wax, L.M. and Hart, S.E. (2003) Glyphosate Translocation in Common Lambsquarters (Chenopodium album) and Velvetleaf (Abutilon theophrasti) in Response to Ammonium Sulfate. Weed Science, 51, 151-156.

http://dx.doi.org/10.1614/0043-1745(2003)051[0151:GTICLC]2.0.CO;2

Submit or recommend next manuscript to SCIRP and we will provide best service for you:

Accepting pre-submission inquiries through Email, Facebook, LinkedIn, Twitter, etc. A wide selection of journals (inclusive of 9 subjects, more than 200 journals)

Providing 24-hour high-quality service

User-friendly online submission system

Fair and swift peer-review system

Efficient typesetting and proofreading procedure

Display of the result of downloads and visits, as well as the number of cited articles Maximum dissemination of your research work

Submit your manuscript at: http://papersubmission.scirp.org/

Or contact as@scirp.org 